\title{
KONSERWACJA XVI-WIECZNEJ POWIEŚCI ALEGORYCZNEJ DESIDEROSVS ZE ZBIORÓW BIBLIOTEKI OPACTWA BENEDYKTYNEK W KRZESZOWIE
}

\section{Wstęp}

Przedmiotem przeprowadzonych prac konserwatorskich był XVI-wieczny druk Desiderosvs, Abo Scieszka Do Milosci Bozey Y Do Doskonalosci Zywota Chrzescianskiego: Dialog dziwnie nabożny y ucieszny, z Hiszpańskiego na Włoski, Francuski, Niemiecki, Niderlandski Y Laciński ięzyk, a teraz na Polski nowo przełożony przez Gaspra Wilkowskiego.... Tekst prawdopodobnie jest dziełem autorstwa Miquela Colomada, hiszpańskiego pisarza religijnego, który był hieronimitą w klasztorze koło Barcelony ${ }^{1}$. Oryginalne dzieło w języku katalońskim, pod tytułem Spilli de la vida religiosa, zostało opublikowane w 1515 r. w Barcelonie, przez Joana Rosenbacha z Heidelbergu. Utwór nawiązuje do prężnego, religijnego nurtu odrodzenia, tzw. devotio moderna, którego głównym ośrodkiem był klasztor na Montserrat w Katalonii. Spili de la vida religiosa, to religijna powieść alegoryczna $^{2}$, adresowana do różnych adresatów, choć głównie do osób duchownych.

* Agnieszka Bangrowska - dr chemii; adiunkt w Zakładzie Ochrony i Konserwacji Zbiorów Bibliotecznych, Instytut Bibliotekoznawstwa, Uniwersytet Śląski; e-mail: bakalarzadr@poczta. onet.pl

ORCID 0000-0002-5151-7099

** Tadeusz Maciąg - mgr biologii, pracownik Zakładu Ochrony i Konserwacji Zbiorów Bibliotecznych, Instytut Bibliotekoznawstwa, Uniwersytet Śląski; e-mail: tadeusz.maciąg@us.edu.pl

ORCID 0000-0002-3234-3951

${ }^{1}$ A. Bover, The spill de la vida religiosa (Barcelona ISIS) and its luso-hispanic transmission w: Multicultural Iberia. Language, literature, and music pod red. D. Dougherty, M.M. Azevedo. Berkeley 1999, s. 57, cyt. za: J. Gwioździk, Desiderosus czyli o pobożnych staraniach księcia Mikołaja Krzysztofa Radziwiłta. „Rocznik Biblioteki Narodowej”, 41 (2009) s. 162.

${ }^{2}$ B. Cieszyńska, Alegoryczna ścieżka do Miłości Bożej. O „,Desiderosusie...” Kaspra Witkowskiego, w: Człowiek w drodze, t. 1, Droga w świecie literackim, Bydgoszcz 2000, s. 57-68, cyt. za Gwioździk, Desiderosus, s. 161. 
O jego popularności świadczy fakt, że w XVI i XVII wieku dzieło thumaczone było na kilkadziesiąt języków, m.in. portugalski, hiszpański, włoski, francuski, niemiecki niderlandzki, duński, gaelicki, angielski ${ }^{3}$. Translacja łacińska była dziełem Suriusa oraz Arnoldsa Van der Meera ${ }^{4}$. Przekładu z łaciny na język polski dokonał Kasper Wilkowski ${ }^{5}$. Ukończył on studia medyczne w Niemczech i we Włoszech. Po zamieszkaniu w Lublinie prowadził praktykę lekarską, następnie przeniósł się do Wilna, gdzie został nadwornym lekarzem Mikołaja Krzysztofa Radziwiłła „Sierotki”. Wiązało się to również z jego konwersją na katolicyzm (prawdopodobnie pod koniec życia został duchownym ${ }^{7}$ ), co odbiło się szerokim echem w ówczesnym środowisku arian polskich ${ }^{8}$. Wilkowski potraktował swoją pracę jako formę zadośćuczynienia za swoją postawę przed konwersją, o czym szerzej pisze w przedmowie adresowanej przede wszystkim do osób duchownych. Jego praca wpisuje się ponadto w działania adresata dedykacji, księcia Mikołaja Krzysztofa Radziwiłła „Sierotki”, który na Litwie wprowadzał katolicyzm. Patronował on m.in. jezuitom, fundował i uposażył ich domy w Wilnie i Nieświeżu (gdzie także wybudował klasztor dla benedyktynek, które przyjęły reformę życia zakonnego po Soborze Trydenckim), zmienił profil założonej przez ojca drukarni w Brześciu Litewskim. Nieprzypadkowo również Desiderosus został wydrukowany w 1589 r. Krakowie, w drukarni Andrzeja Piotrkowczyka.

${ }^{3}$ A. Bover, Tradizione e modernita a ll'inizio del cinquecento. I.o „Spilide la vida religiosa” (ISIS), a Barcellona a Cracovia, w: Tradition et modemite Actes du Colloque du Centenaire de la philologie romane a 1́Universite Jagellonne de Kraków, ed. U. Dąmbska-Prokop, A. Drzewicka. Kraków 1993, s. 53-56, cyt. za Gwioździk, Desiderosus, s. 162, por. tejże: Historyczne kolekcje klasztorne. Zarys problematyki badań, w: Bibliologia. Problemy badawcze nauk humanistycznych, red. D. Kuźmina, Warszawa 2007, s. 167-175.

${ }^{4}$ K. Estreicher, Bibliografia polska, t. 33, Kraków 1939, s. 20-21.

${ }^{5}$ A. Bovcr, Desiderosus albo ścieżka do Miłości Bożej i do doskonatości żywota chrześcijańskiego. Polski przektad XVI-wiecznej anonimowej powieści katalońskiej ,Spili de la vida religiosa Studia iberystyczne. Almanach kataloński, red. T. Kminowicz-Jaśkowska, F. Nawrocka, Kraków 2005, s. 171-182.

6 H. Lulewicz, Radziwitt Mikołaj Krzysztof, w: Polski Stownik Biograficzny, t. 30, Wrocław 1987, s. 349-361; T. Kempa, Mikołaj Krzysztof Radziwilt Sierotka (1549-1616), wojewoda wileński, Warszawa 2000, s. 36-37.

${ }^{7}$ Literatura ariańska w Polsce XVI wieku : antologia. Oprac., wstęp i przypisy Lech Szczucki i Janusz Tazbir, Warszawa 1959, s. 651.

${ }^{8}$ Zob. tekst K. Wilkowskiego, wydany jego nakładem: Przyczyny Nawrocenia do wiary Powszechney od Sekt Nowokrzczeńcow samosateńskich, Wilno 1583 (dostępna http://www.dbc. wroc.pl/dlibra/publication?id=10706\&tab=3). Por. replikę Jana Niemojewskiego (Odpowiedzi na potwarzy Wilkowskiego) oraz List Balcera Wilkowskiego, ojca, do Kaspra Wilkowskiego, doktora, syna swego, do papiestwa przepadtego, datowany 19 kwietnia 1583 r. Zob. także G. Tradel: Iudicium und Ableinung uber ein erschreckliche, Gottslästerliche, Arrianische in Poln... Frankfurt: Christian Erben, 1596. Opracowanie: R. Montusiewicz, Wokót dramatów i dylematów lat reformacji i kontrreformacji. O konwersji Kaspra Witkowskiego, lekarza lubelskiego „Kalendarz Lubelski”, 1982 (http://biblioteka.teatrnn.pl/dlibra/Content/9324/Wokol_dramatow.pdf), S. Baczewski, Literackie świadectwo konwersji: Sprawa Kaspra Wilkowskiego, „Annales Universitatis Mariae Curie-Skłodowska" Sectio FF, Philologiae 2005, s. 75-90; Por. A. Grabowski, Starożytności Historyczne Polskie, czyli pisma i pamiętniki do dziejów dawnej Polski... T. 1. Kraków 1840, s. 479-492. 
Andrzej Piotrkowczyk pochodził z Piotrkowa. W 1574 r. uzyskał obywatelstwo krakowskie i przybrał nazwisko od miasta swojego pochodzenia. W 1576 r. założył drukarnię przy ul. Stolarskiej w Karkowie. W drukarni tłoczono liczne druki religijne (głównie z zakresu teologii duchowości, hagiografie, traktaty teologiczne i kazania oraz literaturę polemiczną). Profil edytorski był zbieżny z podejmowanymi wówczas działaniami kontreformacyjnymi, stąd autorami wielu prac byli zakonnicy, m.in. wydano tu dzieła Piotra Skargi (Żywoty Świętych) czy Jakuba Wujka (postylla i tłumaczenie Biblii). Drukarz krakowski publikował ponadto teksty polityczne, druki okolicznościowe, prace medyczne, prawnicze, podręczniki oraz literaturę piękną (m.in. poezje Jana Kochanowskiego, utwory Szymona Szymonowica). A. Piotrkowczyk w 1607 r. rozpoczął wydawanie druków urzędowych, m.in. konstytucji sejmowych, statutów, uniwersałów. Przywilej ten przejął po Janie Januszowskim (Drukarnia Łazarzowa) ${ }^{9}$. Ogółem oficyna Piotrkowczyka wydała 427 tytułów, z reguły bogato ilustrowanych, doskonałej jakości edytorskiej. Literatura religijna stanowiła 51,6\%, a świecka 48,4\% ogółu opublikowanych pozycji.

Desiderosvs zawiera 154 karty zadrukowane obustronnie. Pierwsze 18 kart nie ma numeracji, następnie zamieszczono 128 kart numerowanych i 8 kart nienumerowanych. Na karcie 38 został błędnie wydrukowany numer 28. Opis fizyczny przedstawia się następująco: [18], 128, [8] k., sygn. )(8, )( $)(10$, A-R8; $8^{\circ}$. Książka jest niewielka: wymiary bloku książki wynoszą $15 \times 10 \mathrm{~cm}$. Wkład książki jest wieloskładowy. Liczba składek wynosi 19, w tym 18 składek jest 16. stronicowych, a jedna 20. stronicowa. Druga składka w kolejności ułożenia jest 20. stronicowa.

Książka wydrukowana jest na papierze czerpanym, o niejednorodnej gramaturze. Masa papieru wyrażona w gramach na metr kwadratowy waha się w granicach od $52 \mathrm{~g} / \mathrm{m}^{2}$ do $76 \mathrm{~g} / \mathrm{m}^{2}$. Druk nie ma żadnych iluminacji. Na kartach książki znajdują się dwa znaki własnościowe w postaci pieczątek. Pierwsza o treści Pieczęć Konwentu Panien Benedyktynek Lwowskich druga Opactwo P.P. Benedyktynek Krzeszów pow. Kamienna Góra. Na stronie tytułowej i ostatniej karcie widnieje ręczny atramentowy zapis To książka nowicyacka ${ }^{10}$ (w ten sposób wskazano jej wykorzystanie w opactwie).

Składki zszyte są na sznurkowe pojedyncze zwięzy (rys. 1). Występują 2 zwięzy prawdziwe i 2 fałszywe. Końcówki konstrukcyjnych sznurków (wąsów) wystające poza grzbiet nalepione były na deski okładkowe. Zwięzy fałszywe były doklejone na wzmacniający grzbiet pasek pergaminowy. Dodatkowo do wzmocnienia grzbietu użyto dwu pasków pergaminowych, umieszczonych na końcach grzbietu. Na zakończeniach grzbietu znajdowały się kapitałki. Blok książki oprawiony był w skórę cielęcą brązową (w dwu kawałkach) ozdobioną złoconymi tłoczeniami (plakietą i tłokami). Układ kompozycyjny zachowanej oprawy w podziale na zwierciadło i bordiurę. W zwierciadle wytłoczona pozłacana owalna plakieta

${ }^{9}$ Drukarze dawnej Polski od XV do XVIII wieku, praca zbiorowa. T. 1, Małopolska. Cz. 1, Wiek XV-XVI, red. A. Kawecka-Gryczowa, Wrocław 1983, s.147-169.

${ }^{10} \mathrm{Na}$ temat obecności książki w zbiorach benedyktynek lwowskich zob. J. Gwioździk, Biblioteka panien benedyktynek łacińskich we Lwowie (XVI-XVIII wiek), Katowice 2001. 
przedstawiająca Ukrzyżowanie Chrystusa. Warsztatu introligatorskiego najpewniej należałoby się doszukiwać w środowisku krakowskim, co jednak wymaga odrębnych analiz.

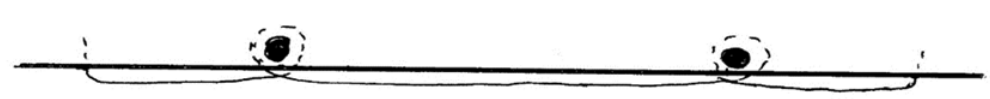

Rys. 1. Schemat szycia bloku

Występująca w konserwowanym obiekcie oprawa to oprawa organiczna: materiał pokryciowy skóra, był naklejony bezpośrednio na grzbiet wkładu. Grzbiet bloku książki prosty. Występowała zapewne także wyklejka. Zachowana tylko tylna okładzina, wykonana była z drewna bukowego. Jej stan zachowania okazał się dobry. Po wyczyszczeniu i uzupełnieniu uszkodzeń ponownie została wykorzystana do oprawy starego druku. Zachowały się również na niej dwa elementy metalowe, mocno skorodowane, służące do mocowania rzemyków z zapinkami.

\section{Charakterystyka zniszczeń}

Książka przed konserwacją była w złym stanie. Brakowało przedniej okładziny. Skórzany grzbiet książki był mocno zniszczony i tylko częściowo przyklejony do grzbietu. W skórzanym grzbiecie widoczne były ślady po żerowaniu owadów. Skóra na tylnej okładzinie na krawędziach była przetarta, a lico zachowanej skóry częściowo wytarte z miejscowymi ubytkami. Skóra występowała w dwóch kawałkach sklejonych ze sobą. Paski pergaminowe wzmacniające grzbiet bloku książki były uszkodzone. Szycie książki zachowane było w dość dobrym stanie, tyko częściowo nici lniane w paru miejscach były przerwane. Karta tytułowa została mocno zniszczona i oderwana od bloku książki (zdjęcie 8), dodatkowo wyrwana była karta piętnasta. Na kartach widoczne były liczne zabrudzenia i zaplamienia, a także rozdarcia, pęknięcia i ubytki. Na wewnętrznej stronie okładziny zachowała się mocno zniszczona karta, które pełniła funkcję wyklejki. Brak było drugiej część tej karty przylegającej do bloku książki. Do klejenia poszczególnych elementów książki wykorzystywany był klej zwierzęcy.

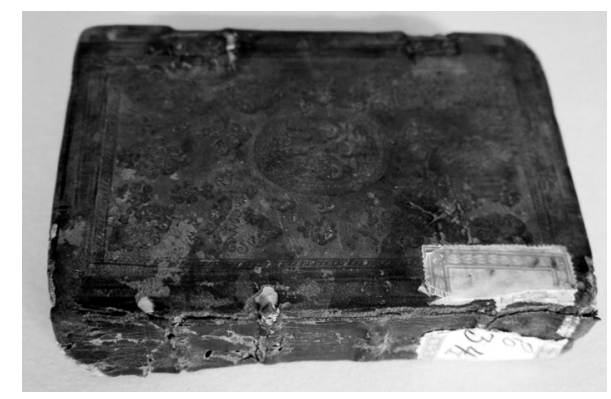

Fot. 1. Książka przed konserwacją.

Fot. T. Maciąg. 


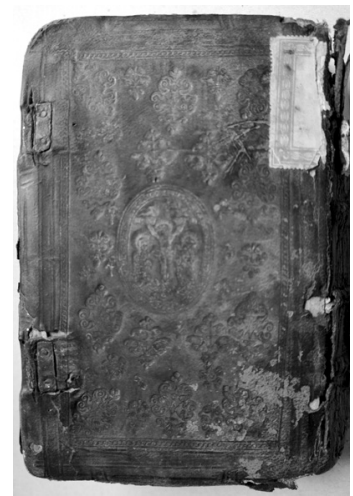

Fot. 2. Książka przed konserwacją. Fot. T. Maciąg.

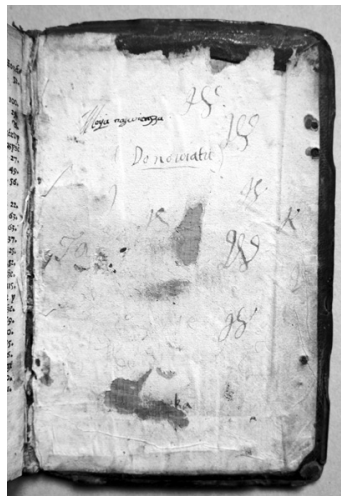

Fot 3. Strona wewnętrzna okła- Fot. 4. Zaplamienia na kartach dziny tylnej. Fot. T. Maciąg.

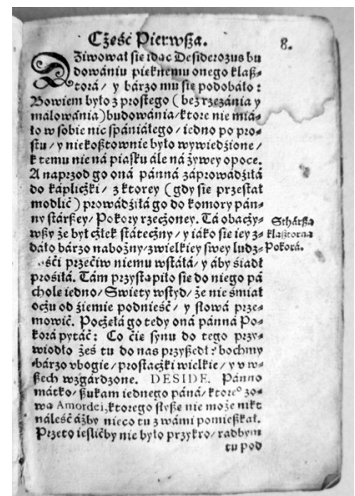

książki. Fot. T. Maciąg

\section{Zakres i przebieg prac konserwatorskich}

Przed podjęciem prac konserwatorskich wykonano dokumentację fotograficzną i opisową, z uwzględnieniem analiz historycznych dotyczących rekonstrukcji oprawy. Wykonano badania laboratoryjne papieru: zbadano $\mathrm{pH}$ papieru, skład włóknisty, grubość i gramaturę. Oznaczenie kwasowości papieru wykonywano metodą kontaktową z wykorzystaniem pH-metru Elmetron CX-741, z elektrodą zespoloną EPX-3 z opcją automatycznego ustalenia końca pomiaru. Stopień zakwaszenia obiektu obrazuje tabela 1. Wyniki wykazały, że papier jest lekko zakwaszony i zostanie poddany odkwaszeniu. Przeprowadzona próba wybarwiania włókien odczynnikiem Herzberga pozwoliła na ustalenie składu papieru, który wyprodukowano z włókien lnianych ${ }^{11}$.

Tabela 1. Wartości pH papieru przed zabiegiem odkwaszania

\begin{tabular}{|l|c|c|c|c|c|c|}
\hline & \multicolumn{7}{|c|}{ Wartość pH } \\
\hline PAPIER & & & & & & Średnia \\
\hline Karta tytułowa & 5,85 & 5,94 & 6,06 & 6,09 & 5,98 & $\mathbf{5 , 9 8}$ \\
\hline karta [10] & 6,26 & 6,01 & 6,11 & 6,14 & 6,43 & $\mathbf{6 , 1 9}$ \\
\hline Karta 40 & 6,26 & 5,99 & 6,19 & 6,24 & 6,09 & $\mathbf{6 , 1 5}$ \\
\hline karta 80 & 5,87 & 6,03 & 6,11 & 6,27 & 6,19 & $\mathbf{6 , 0 9}$ \\
\hline karta ostatnia & 5,74 & 5,81 & 6,19 & 6,07 & 5,96 & $\mathbf{5 , 9 5}$ \\
\hline SKÓRA & & & & & & \\
\hline Oklejka tylna & 4,79 & 5,15 & 5,24 & 4,99 & 5,09 & $\mathbf{5 , 0 5}$ \\
\hline
\end{tabular}

Źródło: opracowanie własne A. Bangrowska.

${ }^{11}$ PN-92/P-50116/03. Papier, tektura, masy włókniste. Oznaczanie składu włóknistego. Część 2. Próba wybarwiania odczynnikiem Herzberga. 
Ponieważ stwierdzono obecność śladów po pleśniach przy grzbietach składek, przeprowadzono badania mikrobiologiczne. W tym celu, pobrano sterylnym wacikiem próbki z miejsc występowania grzybów, które przenoszono na szalki Petryego z podłożem mikrobiologicznym Sabourauda i Czapka ${ }^{12}$. Próbki inkubowano $\mathrm{w}$ cieplarce $\mathrm{w}$ temperaturze $25^{\circ}$, zanalizowano tempo wzrostu wyrastających kolonii w celu określenia żywotności pleśni występującej na badanym obiekcie. Stwierdzono szybki rozrost grzybni, co wskazuje na obecność w badanym materiale żywej grzybni ${ }^{13}$. W związku z tym papier poddano dezynfekcji. Wyizolowane z obiektu grzyby zakwalifikowano do trzech gatunków: Chaetomium globosum, Alternaria alternata i Aspergillus Niger (fot. 5,6.7)

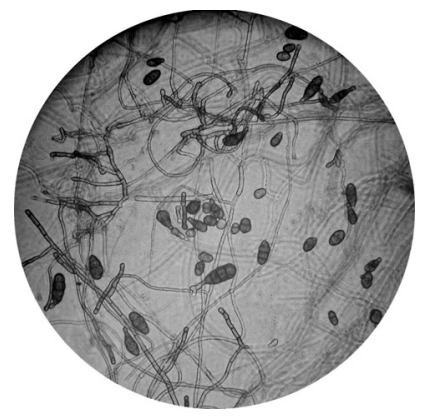

Fot. 5. Alternaria alternata. Fot. A. Bangrowska.

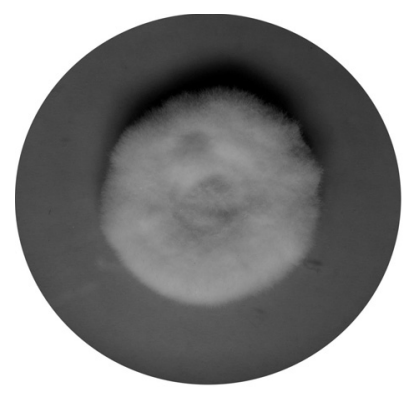

Fot. 6. Chaetomium globosum Fot. A. Bangrowska.

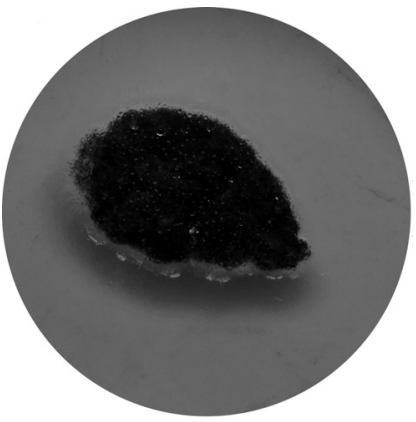

Fot. 7. Aspergillus Niger.

Fot. A. Bangrowska.

Na etapie planowania zabiegów założono, że niezbędny będzie demontaż całego egzemplarza ze względu na znaczny stopień zniszczenia oprawy i kart bloku książki. Blok książki został oddzielony od oprawy, a składki rozłożono na poszczególne karty. Z grzbietu kart zewnętrznych składek usunięto mechanicznie pozostałości wyschniętego kleju zwierzęcego. Wykonano foliację konserwatorską w lewym dolnym rogu, tylko na kartach nienumerowanych. Karty papieru oczyszczono na sucho za pomocą gum różnej twardości.

Po wykonaniu próby odporności farby drukarskiej na wodę, karty papierowe poddano kąpieli dezynfekcyjnej w sterinolu. Po kąpieli trwającej kilkanaście minut, przeprowadzono kilkukrotne płukanie obiektu w czystej wodzie destylowanej dla usunięcia zaadsorbowanego środka. Po tym zabiegu przeprowadzono właściwą kąpiel kart w letniej wodzie z dodatkiem mydła szarego. Płukanie papieru $\mathrm{w}$ wodzie doprowadziło do usunięcia zacieków i zaplamień oraz rozjaśniło pociemniałe podłoże. Kąpiel przyczyniła się do znacznego usunięcia z zabytko-

${ }^{12}$ O. Fasatiowa, Grzyby mikroskopowe w mikrobiologii technicznej, Warszawa 1983, s. 32.

${ }^{13}$ L. Ogierman, Konserwacja zabytkowego materiału bibliotecznego krakowskich paulinów na Skatce, Katowice 2005, s. 19. 
wych papierów starych klejów, przywróceniu im pierwotnej elastyczności oraz usunięcia z papieru tych substancji kwaśnych, które są w niej rozpuszczalne ${ }^{14}$.

Mniejsze ubytki papieru uzupełniano ręcznie masą papierową z ICE w Lodzi na stole podciśnieniowym, a duże ubytki i brakującą kartę 15 uzupełniono w maszynie do uzupełnień masą. Następnie na mokro przyklejono karty, używając do tego celu 3\% wodnego roztworu metylocelulozy, jednocześnie poddano papier odkwaszeniu za pomocą wodorotlenku wapnia. Zawarte w papierze substancje kwaśne w kontakcie $\mathrm{z}$ wodorotlenkiem wapnia uległy naturalizacji. W ciągu kilku dni pod wpływem dwutlenku węgla z powietrza nadmiar wodorotlenku przekształcił się w węglan wapnia i stworzył rezerwę zasadową.

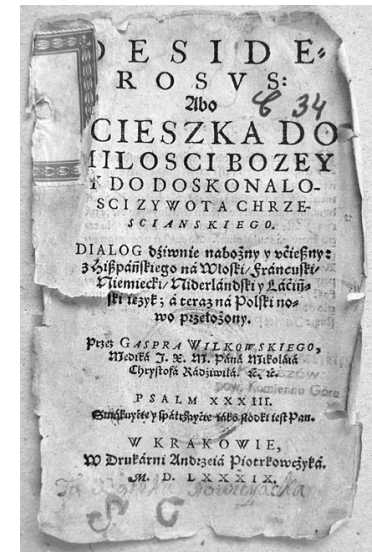

Fot. 8. Karta tytułowa przed konserwacją. Fot. T. Maciąg

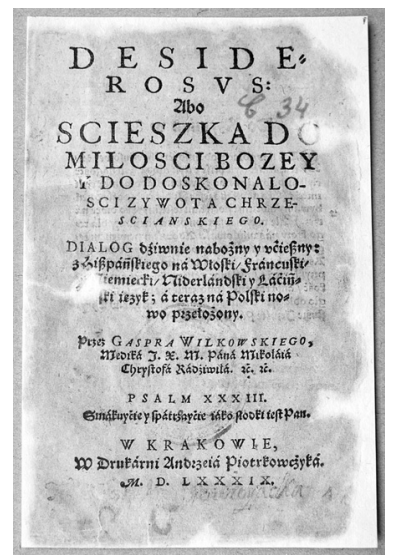

Fot. 9. Karta tytułowa po konserwacji.

Fot. T. Maciąg

Do sporządzenia roztworu metylocelulozy zastosowano wodę wapienną, którą przygotowano poprzez rozpuszczenie 1,6 g wodorotlenku wapnia w 1 litrze wody. Po dwóch tygodniach od przeprowadzenia odkwaszenia zmierzono wartość $\mathrm{pH}$ na tych samych kartkach na których zmierzono kwasowość przed odkwaszeniem. Wyniki przedstawia tabela 2. Po odkwaszeniu wartość $\mathrm{pH}$ papieru wzrosła do około 7,5, zatem ma odczyn lekko zasadowy.

Tabela 2. Wartości pH papieru po zabiegu odkwaszania

\begin{tabular}{|c|c|c|c|c|}
\hline & \multicolumn{4}{|c|}{ Wartość pH po przeprowadzeniu odkwaszania papieru } \\
\hline PAPIER & & & & Średnia \\
\hline $\mathbf{1}$ & $\mathbf{2}$ & $\mathbf{3}$ & $\mathbf{4}$ & $\mathbf{5}$ \\
\hline Karta tytułowa & 7,41 & 7,38 & 7,46 & $\mathbf{7 , 4 1}$ \\
\hline karta [10] & 7,46 & 7,64 & 7,57 & $\mathbf{7 , 5 6}$ \\
\hline
\end{tabular}

${ }^{14}$ W. Sobucki, Odkwaszanie papierów zabytkowych, „Ochrona Zabytków”, 54/1 (212), 2001, s. $63-73$. 


\begin{tabular}{|l|c|c|c|c|}
\hline \multicolumn{1}{|c|}{$\mathbf{1}$} & $\mathbf{2}$ & $\mathbf{3}$ & $\mathbf{4}$ & $\mathbf{5}$ \\
\hline Karta 40 & 7,51 & 7,49 & 7,59 & $\mathbf{7 , 5 3}$ \\
\hline karta 80 & 7,48 & 7,54 & 7,62 & $\mathbf{7 , 5 5}$ \\
\hline karta ostatnia & 7,37 & 7,43 & 7,39 & $\mathbf{7 , 4 0}$ \\
\hline
\end{tabular}

Źródło: opracowanie własne A. Bangrowska.

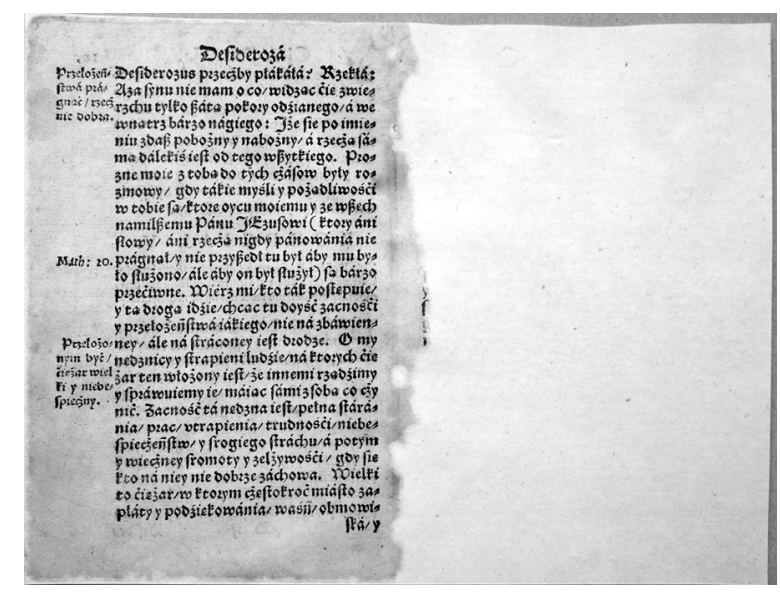

Fot. 10. Uzupełniona masą papierową brakująca karta 15.

Fot. T. Maciąg.

Zaklejone karty suszono i zaprasowywano pod prasą. Miejsca pęknięć kart, a także grzbiety kart zewnętrznych i wewnętrznych składek wzmacniano bibułą japońską o gramaturze 9 i $11 \mathrm{~g} / \mathrm{m}^{2}$ Wykonano wyklejki zgodnie z założeniami plac konserwatorskich.

Złożono i uszyto blok książki według oryginalnych śladów (rys. 1). Zastosowano pojedyncze zwięzy ze sznurka lnianego. Tak jak w oryginale, do wzmocnienia grzbietu użyto trzech pasków wzmacniających, zastosowano gazę introligatorską. Do paska środkowego przytwierdzono zwięzy fałszywe.

Oddzielono skórę z pozostałej okładziny tylnej. Odtworzono przednią okładzinę o wymiarach identycznych jak okładzina tylna, wykorzystując jako materiał drewno bukowe. Zachowaną tylną deskę poddano dezynfekcji alkoholowym roztworem środka owadobójczego o zwyczajowej nazwie permetryna. Skórę pochodząca z oprawy oczyszczono żółcią wołową i uelastyczniono balsamem Maroquin. Wykonano oprawę z nowej skóry cielęcej, garbowanej roślinnie. Oczyszczony i wzmocniony fragment oryginalnej skóry został ponownie naklejony na powierzchnię tylnej okładki. 


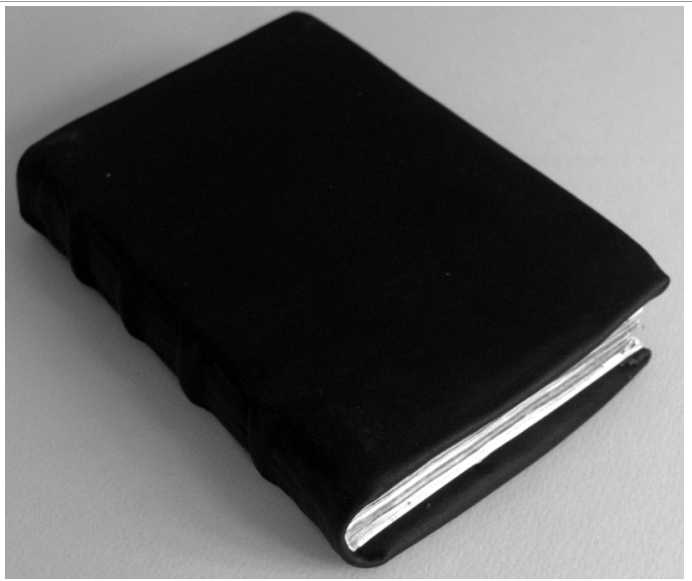

Fot. 10. Widok książki po konserwacji. Fot. T. Maciąg.

Efektem przeprowadzonych zabiegów jest oczyszczenie książki z różnorodnych zanieczyszczeń, wzmocnienie strukturalne papieru, wypłukanie $\mathrm{z}$ niego szkodliwych substancji, uzupełnienie rozdarć i ubytków. Odtworzono także oprawę (wykorzystano drewno bukowe i cielęcą skórę).

\section{Zakończenie}

Ochrona i konserwacja zbiorów bibliotecznych służą zachowaniu dziedzictwa kulturowego. Zakres prac jest odmienny dla różnych typów dokumentów jak książki, grafiki, zbiory archiwalne, rękopiśmienne kodeksy z barwnymi iluminacjami. Jednym $\mathrm{z}$ aspektów ochrony dziedzictwa kulturowego jest kompleksowa ochrona i konserwacja wybranych zbiorów bibliotecznych, możliwa dzięki odpowiednio wykwalifikowanej kadrze oraz przy odpowiednim finansowaniu. Pozyskanie środków pieniężnych umożliwi doposażenie pracowni konserwatorskich w odpowiedni sprzęt, materiały i odczynniki, by wykonać wszelkie prace konserwatorskie w pełnym zakresie oraz zapewni ciągłe dokształcanie kadry specjalistów zajmujących się na co dzień ochroną i konserwacją zbiorów. Może też przyczynić się do nawiązania współpracy międzynarodowej z różnymi ośrodkami badawczymi.

\section{BIBLIOGRAFIA}

PN-92/P-50116/03. Papier, tektura, masy włókniste. Oznaczanie składu włóknistego. Część 2. Próba wybarwiania odczynnikiem Herzberga.

Bover August, The spili de la vida religiosa , "Multicultural Iberia. Language, literature, and music",Berkeley 1999.

Bover August, Desiderosus albo ścieżka do Miłości Bożej i do doskonałości żywota chrześcijańskiego. Polski przektad XVI-wiecznej anonimowej powieści katalońskiej, Spili de la vida religiosa Studia iberystyczne. Almanach kataloński, red. T. KminowiczJaśkowska, F. Nawrocka, Kraków 2005, s. 171-182. 
Cieszyńska Beata, Alegoryczna ścieżka do Miłości Bożej. O „Desiderosusie...” Kaspra Witkowskiego, w: Człowiek $w$ drodze, t. 1, Droga w świecie literackim. Bydgoszcz 2000, s. 57-68.

Drukarze dawnej Polski od XV do XVIII wieku, praca zbiorowa. T. 1, Małopolska. Cz. 1, Wiek XV-XVI, red. Alodia Kawecka-Gryczowa, Wrocław 1983, s. 147-169.

Estreicher Karol, Bibliografia polska, t. 22 (33), Kraków 1939.

Literatura ariańska w Polsce XVI wieku: antologia, oprac., wstęp i przypisy L. Szczucki, J. Tazbir, Warszawa 1959.

Fasatiowa Olga, Grzyby mikroskopowe w mikrobiologii technicznej, Warszawa 1983.

Gwioździk Jolanta, Desiderosus czyli o pobożnych staraniach księcia Mikołaja Krzysztofa Radziwitła, ,Rocznik Biblioteki Narodowej”, 41 (2009) s. 161-172.

Gwioździk Jolanta, Historyczne kolekcje klasztorne. Zarys problematyki badań, w: Bibliologia. Problemy badawcze nauk humanistycznych, red. D. Kuźmina, Warszawa 2007, s. 167-175.

Literatura ariańska w Polsce XVI wieku, antologia, oprac., wstęp i przypisy L.Szczucki, J. Tazbir, Warszawa 1959.

Lulewicz Henryk, Radziwiłt Mikołaj Krzysztof, w: Polski Słownik Biograficzny, t. 30, Wrocław 1987, s. 349-361.

Kempa Tomasz, Mikołaj Krzysztof Radziwitt Sierotka (1549-1616), wojewoda wileński, Warszawa 2000.

Gwioździk Jolanta, Biblioteka panien benedyktynek łacińskich we Lwowie (XVI-XVIII wiek), Katowice 2001.

Ogierman Leonard, Konserwacja zabytkowego materiatu bibliotecznego krakowskich paulinów na Skatce, Katowice 2005.

Sobucki Władysław, Odkwaszanie papierów zabytkowych, „Ochrona Zabytków”, 54/1 (212), 2001, s. 63-73.

\section{KONSERWACJA XVI-WIECZNEJ POWIEŚCI ALEGORYCZNEJ DESIDEROSVS ZE ZBIORÓW BIBLIOTEKI OPACTWA BENEDYKTYNEK W KRZESZOWIE}

\section{Streszczenie}

Badania konserwatorskie i mikrobiologiczne zostały przeprowadzone na XVI wiecznym zbiorze zatytułowany Desiderosvs, Abo Scieszka Do Milosci Bozey Y Do Doskonalosci Zywota Chrzescianskiego: Dialog dziwnie nabożny y ucieszny, z Hiszpańskiego na Włoski, Francuski, Niemiecki, Niderlandski Y Laciński ięzyk, / a teraz na Polski nowo przełożony przez Gaspra Wilkowskiego. Oryginalne dzieło zostało opublikowane w 1515 r. pod tytułem Espill de la vida religiosa. Książka została wydrukowana w Krakowie w 1589 r. w drukarni Andrzeja Piotrkowczyka. Książka wydrukowana jest na papierze czerpanym o niejednorodnej gramaturze w granicach od $52 \mathrm{~g} / \mathrm{m}^{2}$ do $76 \mathrm{~g} / \mathrm{m}^{2}$. Zawiera 154 karty zadrukowane obustronnie, pierwsze 18 kart nie posiada numeracji, następnie występuję 128 kart numerowanych i 8 kart nienumerowanych. Wymiary bloku książki wynoszą $15 \times 10 \mathrm{~cm}$. Wkład książki jest wieloskładowy. Tylna okładzina wykonana była z drewna bukowego. Przed podjęciem prac konserwatorskich wykonano dokumentację fotograficzna i opisową z uwzględnieniem analiz historycznych dotyczących rekonstrukcji oprawy. Wykonano badania laboratoryjne papieru: zbadano $\mathrm{pH}$ papieru, skład włóknisty, grubość 
i gramaturę oraz przeprowadzono badania mikrobiologiczne. Wyizolowane z obiektu grzyby zidentyfikowano do trzech gatunków: Chaetomium globosum, Alternaria alternata $i$ Aspergillus niger. W związku z tym papier poddano dezynfekcji. Po wykonaniu próby odporności farby drukarskiej na wodę, karty papierowe poddano kąpieli dezynfekcyjnej w sterinolu oraz przeprowadzono kilkukrotne płukanie obiektu w czystej wodzie destylowanej następnie przeprowadzono właściwa kąpiel kart $\mathrm{w}$ letniej wodzie $\mathrm{z}$ dodatkiem mydła szarego. Mniejsze ubytki papieru uzupełniano ręcznie masą papierową z ICE w Łodzi na stole podciśnieniowym a duże ubytki i brakującą kartę 15 uzupełniono w maszynie do uzupełnień masą. Następnie na mokro przyklejono karty, używając do tego celu 3\% wodny roztwór metylocelulozy, jednocześnie poddając papier odkwaszeniu. Jako środek odkwaszający użyto wodorotlenek wapnia. Zawarte w papierze substancje o charakterze kwasowym w reakcji z wodorotlenkiem wapnia uległy zobojętnieniu a nadmiar wodorotlenku w ciągu kilku dni pod wpływem dwutlenku węgla $\mathrm{z}$ powietrza dał produkt reakcji czyli węglan wapnia, który stanowi rezerwę alkaliczną. W wyniku przeprowadzonych prac oczyszczono książkę z różnorodnych zanieczyszczeń, wzmocniono strukturę papieru, uzupełniono rozdarcia i ubytki. Odtworzono oprawę wykorzystując drewno bukowe i cielęcą skórę. Dzięki tym badaniom książka przetrwa na kolejne lata i będzie służyć kolejnym pokoleniom.

Słowa kluczowe: konserwacja; kąpiel wodna; sterinol; grzyby; dezynfekcja; ochrona

\section{CONSERVATION OF THE SIXTEENTH-CENTURY ALLEGORICAL NOVEL DESIDEROSVS FROM THE COLLECTIONS OF THE ABBEY LIBRARY OF THE BENEDICTINE SISTERS IN KRZESZÓW}

\section{Summary}

Conservation and microbiological research was carried out on a sixteenth-century collection entitled Desiderosvs, Abo Scieszka Do Milosci Bozey Y To Excellence, Zywota Chrzescianskiego: Dialog strangely devotional, from Spanish to Italian, French, German, Dutch Y Laciński ięzyk, and now for Poland postponed by Gaspra Wilkowski. The original work was published in 1515 under the title Espill de la vida religiosa. The book was printed in Krakow in 1589 at the printing house of Andrzej Piotrkowczyk. The book is printed on a handmade paper with a non-homogeneous basis weight ranging from $52 \mathrm{~g} /$ $\mathrm{m}^{2}$ to $76 \mathrm{~g} / \mathrm{m}^{2}$. It contains 154 cards printed on both sides, the first 18 cards have no numbering, then there are 128 numbered cards and 8 unnumbered cards. The book is small. The dimensions of the book block are $15 \times 10 \mathrm{~cm}$. The contribution of the book is multiple. The rear cladding was made of beech wood. Before conservation works were carried out, photographic and descriptive documentation was made, including historical analyzes of the reconstruction of the luminaire. Paper laboratory tests were carried out: paper $\mathrm{pH}$, fiber composition, thickness and basis weight were tested and microbiological tests were carried out. Mushrooms isolated from the object were identified to three species: Chaetomium globosum, Alternaria alternata and Aspergillus niger. Therefore, the paper was disinfected. After testing the resistance of the printing ink to water, the paper cards were subjected to a disinfectant bath in sterinol and the object was rinsed several times in pure distilled water, followed by a proper bath of cards in lukewarm water with the addition of 
gray soap. Smaller paper losses were supplemented manually with paper pulp from ICE in Lodz on the vacuum table, and large losses and missing card 15 were supplemented with a mass replenishment machine. The cards were then wet-glued using a $3 \%$ aqueous solution of methylcellulose while subjecting the paper to deacidification. Calcium hydroxide was used as deacidifying agent. The acidic substances contained in the paper reacted with calcium hydroxide and the excess of hydroxide in a few days under the influence of carbon dioxide from the air gave the reaction product, i.e. calcium carbonate, which is an alkaline reserve. As a result of the work carried out, the book was cleaned of various impurities, the paper structure was strengthened, tears and cavities were supplemented. The frame was reconstructed using beech wood and calf leather. Thanks to this research, the book will survive for the next years and will serve the next generations.

Key words: conservation; water bath; sterinol; fungi; disinfection; protection

Translated by Agnieszka Bangrowska 